\title{
Marian LUTOSTAŃSKI
}

Państwowa Wyższa Szkoła Zawodowa, Wydział Społeczno-Techniczny, Konin, Polska

\section{Idea wyodrębnienia dyscypliny naukowej „nauki o bezpieczeństwie” i jej konsekwencje}

\section{The Idea of the Separation of Scientific Discipline "the Security Studies" and Its Consequences}

\section{- Abstrakt •}

Dyscyplina naukowa „nauki o bezpieczeństwie" budzi liczne kontrowersje. Zgłaszane uwagi są przedstawiane w kontekście „uspołecznienia bezpieczeństwa” i innej dyscypliny naukowej - „nauki o obronności”. Opracowanie jest próbą udzielenia odpowiedzi na dwa pytania: 1) co stanowi przesłankę do kontestowania (aktualnej) klasyfikacji nauki polskiej w części dotyczącej nauk o bezpieczeństwie?; 2) przyjęcie jakich rozwiązań może wpłynąć na usunięcie kontrowersyjnych kwestii z objętej refleksją klasyfikacji? W artykule zawarto również krótką refleksję dotyczącą ,inżynierii bezpieczeństwa" jako autonomicznej dyscypliny naukowej. W końcowej części rozważań przedstawiono autorski model rozwiązania istniejącego problemu.

Słowa kluczowe: polska klasyfikacja nauk, dziedzina nauk, dyscyplina naukowa, bezpieczeństwo, obronność

\section{- Abstract •}

There are numerous controversies regarding the fields of study of "security". Reported objections are represented in the context of "nationalization" and another field of study - "defense studies". The study is an attempt to answer two questions: 1) what is the rationale to contest the current list of areas of academic study, academic disciplines and fields of study in the area of security and defense studies?; 2) what are the possible solutions to remove controversial issues in that classification? The article also provides a short reflection on the "security engineering" as an autonomous discipline. In the final part of the foregoing shows the original model solutions of an existing problem.

Keywords: Polish classification of sciences, academic disciplines, fields of study in the sciences, security, defense 


\section{Wstęp}

„Nauki o bezpieczeństwie” to jedna z dwóch dyscyplin naukowych, obok „nauk o obronności”, która zajmuje się badaniem problemów bezpieczeństwa narodu i państwa. Wyłonieniu jej towarzyszą liczne kontrowersje, spośród których za główne uważa się trudności z określeniem jej domeny oraz zakresu badań. Sytuacja taka nie sprzyja spójności, jakości oraz przejrzystości nauki, dydaktyki i praktyki ${ }^{1}$. Dostrzegane dylematy sprawiły, że w niniejszym opracowaniu skupiono się na próbie znalezienia odpowiedzi na dwa pytania:

1) co stanowi przesłankę do kontestowania (aktualnej) klasyfikacji nauki polskiej w części dotyczącej nauk o bezpieczeństwie?

2) przyjęcie jakich rozwiązań może wpłynąć na usunięcie dostrzeganych kontrowersji z objętej refleksją klasyfikacji?

Podniesione problemy stały się głównymi determinantami celu opracowania oraz podjętej próby autorskiej projekcji tej części polskiej klasyfikacji nauk. Podstawą rozważań było bezpieczeństwo rozumiane jako zjawisko o charakterze egzystencjalno-rozwojowym narodu i państwa, które będąc powiązane z działami administracji rządowej, stanowi fragment (domenę) bezpieczeństwa konkretnego podmiotu w konkretnej przestrzeni i które jest zapewniane głównie przez wyspecjalizowane formacje państwowe.

Jako że współczesne bezpieczeństwo wymaga technicznego i technologicznego wsparcia o charakterze specjalistycznym, w aktualnej zaś klasyfikacji nauk nie wyodrębniono osobnej dyscypliny naukowej dotyczącej tej kwestii, w artykule zawarto również krótką projekcję ujęcia w polskiej klasyfikacji nauk samodzielnej dyscypliny naukowej pod nazwą „inżynieria bezpieczeństwa”.

\section{Kilka uwag o procesie wyłonienia dyscypliny naukowej „nauki o bezpieczeństwie”}

„Nauki o bezpieczeństwie” zostały wyodrębnione w polskiej klasyfikacji nauk (Rozporządzenie Ministra Nauki i Szkolnictwa Wyższego z dnia 8 sierpnia 2011 r., poz. 1065) jako dyscyplina naukowa. Ich celem było uporządkowanie - w kontek-

${ }^{1}$ Obserwowane zjawisko potwierdza szeroki dyskurs tematyczny, w tym różne formy debat naukowych i dydaktycznych. Artykuł wpisuje się w cykl autorskich rozważań prowadzonych w ramach dyskusji i refleksji naukowej, której przedmiotem są dylematy dyscyplin naukowych nauki o bezpieczeństwie i nauki o obronności. Okoliczność ta sprawiła, że w tym opracowaniu pominięto niektóre kwestie związane z prawnym aspektem ich powołania. 
ście z praktyką - aktywności środowisk naukowych i edukacyjnych. Wskazywało na to wielu badaczy, m.in. Waldemar Kitler, który w swoich tematycznych rozważaniach podnosił, iż nowa klasyfikacja nauk z dyscypliną naukową "nauki o bezpieczeństwie" w dużym stopniu stanowiła wyraz oczekiwań i potrzeb środowiska naukowego (Kitler, 2015). Jednakże zaraz po „uformalnieniu” tej dyscypliny pojawiły się liczne uwagi oraz wątpliwości odnoszące się zarówno do jej domeny, jak i tożsamości. Piotr Sienkiewicz (przykładowo) zauważył, że: „Formalne niejako zadekretowanie nauk o bezpieczeństwie nie rozwiązuje żadnego istotnego problemu, natomiast stawia wiele pytań, a także przynosi wiele - równie istotnych - problemów organizacyjnych w uczelniach prowadzących działalność badawczą i edukacyjną w tym obszarze" (Sienkiewicz, 2013, 2015). Dostrzegając wagą przywołanych spostrzeżeń, warto podnieść, że do obserwowanej konfuzji w zakresie nowo utworzonej dyscypliny naukowej doszło przy udziale Państwowej Komisji Akredytacyjnej oraz Centralnej Komisji do Spraw Stopni i Tytułów Naukowych, a także innych przedstawicieli świata nauki i dydaktyki. Konstatacja taka jednak nie przybliża do wyjaśnienia motywów przyjęcia istotnie problematycznej koncepcji klasyfikacji. Pewne światło na tę kwestię rzuca artykuł Z. Trejnisa (2011). Wynika z niego m.in. konflikt środowisk naukowych o przedmiot badań, który nadal nie został ustalony. Okoliczność taka może uprawniać do stawiania różnych pytań, w tym takie: co stanowiło główną przyczynę, że w polskiej klasyfikacji nauk znalazły się „nauki o bezpieczeństwie”, które - zamiast porządkować aktywność środowisk naukowego i dydaktycznego - same pretendują do problemu badawczego? Jak wynika bowiem z literatury przedmiotu, polska klasyfikacja nauk w części dotyczącej bezpieczeństwa wprowadziła istotne zamieszanie w nauce i dydaktyce (Lutostański, 2015), co niewątpliwie przekłada się także na jakość praktyki. Waldemar Kitler wskazuje, że nauki o bezpieczeństwie budzą wiele kontrowersji, wynikających m.in. z tego, że są naukami wyjątkowo niekonkretnymi (Kitler, 2015). Podobny pogląd prezentuje Ryszard Wróblewski, który wyraźnie podkreśla, że przedmiotem badań dyscypliny naukowej „nauki o bezpieczeństwie” nie może być „bezpieczeństwo wszystkiego” (Wróblewski, 2015). Nawet pogłębiona analiza zjawiska każe zauważyć, że nie jest łatwo znaleźć przekonujący argument, by krytyczne poglądy w tym zakresie uznać za pozbawione racji.

Refleksja nad procesem wyłaniania nauk o bezpieczeństwie pozwala przyjąć, że zarówno koncepcja ich utworzenia, jak i skutki z niej wynikające nie zostały poprzedzone dostateczną analizą, która dostarczyłaby odpowiedzi w szczególności na pytanie: czy zaproponowana typologia odpowiada przyjętym założeniom w związku m.in. z likwidacją dziedziny/dyscypliny nauk wojskowych? W tym miejscu nasuwa się także inne pytanie: czy rzeczywiście mają rację wyraziciele po- 
glądu (Sienkiewicz, 2015), że obecnie nie ma potrzeby rozwijania „filozofii bezpieczeństwa" lub toczenia sporów o nazwy, typologie, klasyfikacje itp.? Wskazując na takie dylematy, wypada zauważyć, że przed formułowaniem kategorycznych, a przy tym kontrowersyjnych uogólnień badacza bezpieczeństwa może ustrzec właściwe nauce - podejście kontekstowe. Warto zatem pamiętać, że kontekst filozoficzny odegrał bardzo pozytywną rolę w innych naukach. Myśl filozoficzna pozwoliła bowiem (na przykład) twórcom współczesnej ekonomii, m.in. Adamowi Smithowi czy Johnowi S. Millowi, osiągnąć sukcesy, a ich projekcje ekonomiczne były przesiąknięte myślą filozoficzną (Wikin, 2012).

Podczas analizy złożonego problemu, zawierającego się w wyodrębnionej w klasyfikacji nauk dyscyplinie "nauki o bezpieczeństwie” nasuwają się również inne wątpliwości, których źródłem jest jednak nie zawsze łatwa do zaakceptowania „filozofia" badania problemów bezpieczeństwa ${ }^{2}$. Preferowana bowiem aktualnie koncepcja nadmiernie rozszerza i zrównuje pierwszorzędne problemy bezpieczeństwa, a więc te rzeczywiście istotne (wynikające niejako z działów administracji państwa) z punktu widzenia trwałości egzystencji określonego podmiotu (z elementem obejmującym jego rozwój ${ }^{3}$ z niewątpliwie ważnymi społecznie, lecz stanowiącymi jednak kwestie kolejnego rzędu ważności („problemy miękkie” o jakościowym, nietrwałym charakterze życia, funkcjonowania oraz rozwoju danego podmiotu $\left.{ }^{4}\right)$. Zdaniem autora, szeroki zakres merytoryczny problematyki bezpieczeństwa, choć bezsprzecznie ważny, zdaje się uprawniać do stwierdzenia, że decydujący o powołaniu „nauk o bezpieczeństwie” (najprawdopodobniej) nie docenili filozoficznej natury bezpieczeństwa. Wygląda na to, że właśnie brak refleksji filozoficznej, płynącej ze złożonej natury bezpieczeństwa, skutkował nietrafną typologią, wyrażającą się m.in. w nazwach dyscyplin naukowych (nauki o bezpieczeństwie i nauki o obronności). Zakres i charakter problematyki bezpieczeństwa, jak się uważa, powinien dostarczyć autorom klasyfikacji nauk przekonujących argumentów, stanowiących logiczne uzasadnienie do wyłonienia nie tylko dyscyplin naukowych o in-

${ }^{2}$ O problemach filozofii bezpieczeństwa bardzo interesująco, a jednocześnie w sposób jasny pisze Pokruszyński, 2011.

${ }^{3}$ Chodzi przede wszystkim o neutralizację zagrożeń, których źródła mogą być zarówno wewnątrz kraju, jak i poza jego granicami, a jednocześnie których rozwiązywanie jest możliwe przy użyciu wyspecjalizowanych narzędzi (zapewniających: ochronę bezpieczeństwa wewnętrznego związanego z zachowaniem porządku publicznego w państwie, ochronę bezpieczeństwa zewnętrznego państwa, a także ochronę specjalną bezpieczeństwa państwa i jego potencjału obronnego). Więcej w: Lutostański, 2014.

${ }^{4} \mathrm{~Np}$. bezpieczeństwo socjalne, ekonomiczne, bezpieczeństwo i higiena pracy, inne, które wpływają na jakość życia i funkcjonowania obywateli oraz instytucji im służących, obniżają różnego rodzaju ryzyka naruszające tę jakość itp. O problemach tych więcej w: Lutostański, 2016. 
nych nazwach, lecz również do powołania samodzielnej „dziedziny nauk o bezpieczeństwie”. Można również się zastanawiać: czy autorzy dyscypliny naukowej nauki o bezpieczeństwie wystarczająco dużo wagi przywiązali (chociaż teza taka jest trudna do przyjęcia) do obserwowalnych zjawisk związanych z bezpieczeństwem, a w szczególności do dotyczących zachowań ludzkich, w tym przywódców państw i ich reakcji na ważne dla bezpieczeństwa określonych podmiotów bodźce, uwarunkowania wewnętrzne i zewnętrzne? Aktualną sytuację, charakteryzującą się swoistym „rozmyciem” problemów o charakterze egzystencjalnym, może tłumaczyć, choć autora to nie w pełni przekonuje, zachodni trend (np. koncepcje Barry'ego Buzana). Znajdujemy w nim istotne „uspołecznienie bezpieczeństwa”, które wyraża się w postrzeganiu wszelkich zjawisk społecznych, jako problemów bezpieczeństwa o mocno zbliżonym znaczeniu. Wskazując na ten aspekt, warto jednocześnie powołać się na casus innych nauk i zauważyć, że przywołany trend zawiera pewną niekonsekwencję, wyrażającą się (przykładowo) w braku (stypendystów) przedstawicieli nauk o bezpieczeństwie w Centrum Zaawansowanych Badań w Naukach Behawioralnych Uniwersytetu Stanforda (Center for Advanced Study in the Behavioral Sciences at Stanford University; za: Wikin, 2012) ${ }^{5}$. Być może ma to związek z tym, że na Zachodzie nieco inaczej przebiegają procesy badawcze w obszarze bezpieczeństwa. Zamiast dyscypliny naukowej „nauki o bezpieczeństwie" są tam studia nad bezpieczeństwem (Wróblewski, 2015). Nadanie zatem wąskiemu elementowi nauki, jaką stanowi dyscyplina naukowa nauki o bezpieczeństwie, multidyscyplinarnego charakteru nie musi być rozwiązaniem oczywiście pozytywnym. Koncepcja taka może wpływać bowiem na powstawanie tarć semantycznych wewnątrz dyscypliny i w konsekwencji generować destrukcyjne zamieszanie terminologiczne oraz metodologiczne. I tu należy przyznać rację P. Sienkiewiczowi, który w takiej koncepcji zasadnie dostrzega mnożenie pytań, a także możliwość zatarcia tożsamości nauk. Powstała sytuacja przyczynia się również do rozszerzania kręgu badaczy, a nawet „ekspertów działających pod szyldem" nauk o bezpieczeństwie (od globalnego bezpieczeństwa militarnego przez bezpieczeństwo społeczne, kulturowe, socjalne, żywnościowe, przeciwpożarowe do stanowiska pracy, a nawet o jeszcze węższym zakresie). Uwzględniając powyższe, można spytać: czy twórcy dyscypliny nauk o bezpieczeństwie brali pod uwa-

5 Podniesienie tej kwestii wynika z faktu, iż wśród dotychczasowych członków stypendystów (fellows) Centrum znalazło się 22 laureatów Nagrody Nobla, 14 laureatów Nagrody Pulitzera i wielu innych laureatów prestiżowych nagród. Obecnie wśród stypendystów Centrum znajdują się przedstawiciele następujących dyscyplin: kognitywistyka, psychologia, socjologia, ekonomia, historia, informatyka, prawo, nauki polityczne, komunikacja medialna, lingwistyka, literatura i religioznawstwo. 
gę rzeczywisty zakres badań i oryginalność warsztatu metodologicznego przynależne tej dyscyplinie? Równocześnie można wyrazić nadzieję, że odczuwalne obecnie zamieszanie w obrębie nauk o bezpieczeństwie paradoksalnie może doprowadzić do szybszego skonkretyzowania paradygmatu o bezpieczeństwie narodu i państwa.

Niejako w reasumpcji powyższych rozważań, parafrazując wypowiedź jednego z najwybitniejszych ekonomistów P. Samuelsona, który na kanwie sporów o uporządkowanie wiedzy w ekonomii zauważył, że „ekonomia to najstarsza ze sztuk i najmłodsza nauk” (Wikin, 2012), można powiedzieć, że „bezpieczeństwo, choć należy do najstarszych ze sztuk, to wydaje się wciąż jedną z najmłodszych nauk".

\section{O wybranych przesłankach uprawniających kontestowanie polskiej klasyfikacji nauki w części dotyczącej nauk o bezpieczeństwie}

Dostrzegając niedoskonałości polskiej klasyfikacji nauki w części dotyczącej nauk o bezpieczeństwie, warto poświęcić więcej uwagi trzem ważnym problemom (wspomniano o nich powyżej), które pozostają w ścisłym związku z „całokształtem bezpieczeństwa" i jego metodologią, a więc na: przedmiot badań, zakres badań oraz terminologię badań.

Warto zatem podkreślić odczuwalny brak sprecyzowanego przedmiotu badań nauk o bezpieczeństwie. Brak taki oznacza, że niełatwo wskazać, „czym dokładnie mają się zajmować owe nauki" (Jarmoszko, Kalita, Maciejewski, 2016), a jednocześnie sprawia, że przedmiotem badań jest wszystko, co się wiąże z bezpieczeństwem - od skomplikowanych, globalnych militarnych i niemilitarnych systemów bezpieczeństwa do prostych zdarzeń dotyczących jakości egzystencji pojedynczego człowieka. Niewątpliwie szeroka płaszczyzna bezpieczeństwa nie podlega kontestowaniu, ponieważ problemy bezpieczeństwa, nawet te o charakterze globalnym z elementami kosmosu, podobnie jak np. kiepskiej jakości sztućce, dotyczą w gruncie rzeczy bezpieczeństwa pojedynczego człowieka. Niemniej jednak w rozważanej sytuacji kwestia ta staje się niejako kanwą mnożenia wątpliwości i pytań, m.in. o to: czy dyscyplina naukowa nauki o bezpieczeństwie odpowiada wymogom definicyjnym jako takiej dyscypliny naukowej (Krzyżanowski, 1999; Szaruc$\mathrm{ki}^{6}$. Mając na uwadze wnioski, jakie można wywieść z definicji dyscypliny nauko-

${ }^{6}$ Według Leszka Krzyżanowskiego, dyscyplina naukowa (w ujęciu instytucjonalnym) to: „doniosła społecznie, ukształtowana i wyodrębniona ze względu na przedmiot i cel badań lub kształcenia część nauki w znaczeniu instytucjonalnym uznana za podstawową jednostkę jej klasyfikacji”. 
wej i odniesienie ich do dyscypliny nauki o bezpieczeństwie nietrudno zauważyć, że problem tych nauk nie polega wyłącznie na braku określenia wyraźnego przedmiotu badań, który niewątpliwie powinien być możliwy do wskazania w oparciu na podstawowych kategoriach zawartych w tej dyscyplinie. Występuje tu bowiem także kwestia zakresu badań, która się wiąże z problematycznością delimitacji badań tej dyscypliny naukowej, zwłaszcza że bezpieczeństwo jest generalnie zjawiskiem wielowymiarowym i rozprzestrzenionym, a to oznacza, że należy badać je pod względem wielu cech. Zakres badań wydaje się ważny również ze względu na to, że w tej samej klasyfikacji znajduje się inna dyscyplina naukowa nauki o obronności, która - jak wiadomo - poprzez przedmiot i cele procesu poznawania, język oraz metody badawcze pozostaje w związku z naukami o bezpieczeństwie (Kitler, 2015). Warto podnieść, że w obecnym rozwiązaniu klasyfikacyjnym nauki o obronności mogą być rozpatrywane również jako przedmiot badań nauk o bezpieczeństwie (Lutostański, 2015). I choć kwestia nie tkwi w tym, że nauki o obronności zajmują się problemami bezpieczeństwa, jako że ich zarówno formalny, jak i materialny przedmiot badań może się pokrywać w jakiejś części z przedmiotem badań innej dyscypliny naukowej, to powinno go jednak odróżniać widzenie badanej rzeczywistości. Ponieważ delimitacja badań wiąże się z terminologią, która powinna być typowa dla danej dyscypliny naukowej, to przy braku wyraźnego zakresu badań istotnie rozprzestrzenionej problematyki bezpieczeństwa powstaje pytanie: czy obecna sytuacja nie powoduje nadmiernej niejasności i zamieszania w nauce, teorii, dydaktyce oraz praktyce bezpieczeństwa? Odpowiedzią na to pytanie może być, podzielane przez autora, dość jednoznaczne stanowisko W. Kitlera, który wskazuje m.in., że: „Chaos terminologiczny w naukach o bezpieczeństwie utrudnia możliwość komunikowania się w ramach zwięzłej teorii, a także stwarza możliwość dowolnego jej stosowania, co prowadzi do braku logicznie powiązanych tez, hipotez, praw i definicji jednoznacznie wyjaśniających określony przedmiot badań" (Kitler, 2015). I choć nie jest to jedyny głos w tej kwestii, to jego jednoznaczność wyraźnie potwierdza, że dyscyplina naukowa nauki o bezpieczeństwie jest mało konkretna. Z faktu tego wynikają liczne wątpliwości, np. czy dyscyplina ta wyczerpuje znamiona dyscypliny naukowej, a więc koniecznego, konkretnego wydzielenia badanej przestrzeni, skatalogowania wielowymiarowego, rozprzestrzenionego bezpieczeństwa? Warto zaznaczyć, że idzie tu przede wszystkim o postrzeganie nauk o bezpieczeństwie jako działalności naukowej opartej na teorii i metodologii właściwej dyscyplinie naukowej (kwestia zasadnicza), mniej zaś na przymiotach przysługujących ekspertowi (kwestia wtórna). Kontestowane więc aspekty dyscypliny naukowej nauki o bezpieczeństwie, w świetle chociażby jednego z paradygmatów nauk, jakim jest ścisłość terminolo- 
giczna, nie mogą być tłumaczone złożonością i wielowymiarowością bezpieczeństwa, a także - z uwagi na rozprzestrzenione właściwości zjawiska - potrzebą jego interdyscyplinarnego badania.

\section{Projekcja rozwiązań w zakresie nauk dotyczących problematyki bezpieczeństwa}

Fakt wskazania na projekcję rozwiązania opisywanego powyżej problemu polskiej klasyfikacji nauk w części dotyczącej nauk związanych z bezpieczeństwem oznacza, że autor podziela spotykany w literaturze przedmiotu pogląd o zasadności myślenia i działania naukowego w ramach dyscyplin naukowych (Szczepański, 2013). W preferowanym podejściu autor uwzględnia także fakt, iż obecnie w praktyce (tak było w przeszłości i pewnie tak będzie w przyszłości) jest niezaprzeczalnie trudno zachować pełną i optymalną delimitację aktywności naukowej, a więc prowadzenie badań opartych wyłącznie na osiągnięciach jednej dyscypliny naukowej. Mimo dostrzeganych trudności, pogłębiona refleksja utwierdza autora w przekonaniu, że jego projekcja wyodrębnienia nauk dotyczących bezpieczeństwa (prezentowana w jego, wspomnianych powyżej, opracowaniach) jest trafniejsza zarówno od obowiązującej klasyfikacji, ponieważ polaryzuje obszary i zakresy badań, jak i od poglądu postdyscyplinarnego preferującego odejście od wydzielania dyscyplin naukowych i uzasadnianego przenikaniem się metod i zakresów dociekań.

Akceptując systematyzację nauki z uwzględnieniem dyscyplin naukowych, warto powtórzyć za Jarosławem Szczepańskim, że: „(..) Podstawą wyróżnienia dyscypliny jest przedmiot badań w znaczeniu formalnym i cel lub cele badań, których realizacji służy dana nauka”" (Szczepański, 2013). Podzielając takie podejście i przenosząc jego ideę na nauki zajmujące się badaniem problemów bezpieczeństwa konkretnych podmiotów, należy pamiętać, jak była o tym mowa powyżej, że jako takie bezpieczeństwo jest zjawiskiem bardzo pojemnym i o bardzo zróżnicowanym zakresie. Sprawia to, że zachodzi konieczność dokonania odpowiedniego podziału i skatalogowania zakresów bezpieczeństwa. Idzie tu o podział obszaru bezpieczeństwa na dyscypliny, z których nazw będzie wybrzmiewał katalog zjawisk o wspólnym kontekście i osobnym zakresie badań. Sprawi to, że nie będziemy mieli do czynienia z dyscypliną, jak już wskazywano za R. Wróblewskim, której przedmiotem badań jest „bezpieczeństwo wszystkiego”. Wskazana „pojemność" bezpieczeństwa świadczy o jego społecznym charakterze i pozwala zauważyć, że rezultatem takiej operacji może być kilka dyscyplin naukowych jemu po- 
święconych. Sytuacja taka może wskazywać, z jednej strony, na potrzebę uwzględnienia w projekcji podziału nauk o bezpieczeństwie wspólnej dla nich dziedziny naukowej, z drugiej zaś - na zasadność zastosowania takiej metody podziału, która będzie wspólna dla nauki i praktyki. Zastosowanie takiej metody powinno doprowadzić do ograniczenia potencjalnie i realnie nadmiernej liczby dyscyplin. Warto jednocześnie zwrócić uwagę na to, że problematyka bezpieczeństwa znajduje się w obszarze nauk społecznych, które cechuje wyraźna „wspólnota metodologiczna”. Okoliczność tę należy uznać za korzystną i ułatwiającą rozwój nauk o bezpieczeństwie. Jednakże szeroki zakres badawczy oraz jakość i odrębność problemów badawczych względem innych nauk, wynikające z istoty bezpieczeństwa, nakazują dążenie do tworzenia i kształtowania oryginalnego warsztatu metodologicznego właściwego tylko naukom o bezpieczeństwie. Celem takiego działania powinna być (cel pierwotny) optymalizacja badań bezpieczeństwa i (cel wtórny) wniesienie do bogatej metodologii badań nauk społecznych oryginalnego wkładu nauk o bezpieczeństwie.

Mając na uwadze utrudnienia w prowadzeniu działalności naukowej w obrębie dotychczasowych nauk o bezpieczeństwie, które wynikają m.in. z szerokiego zakresu pola badawczego bezpieczeństwa, należy wydzielić z takiego pola część (części) bezpieczeństwa szczególnie ważną dla egzystencji i rozwoju określonego podmiotu. Część taka powinna być wyodrębniona z uwzględnieniem kryterium konkretnej przestrzeni i konkretnego środowiska oraz charakteru i sposobów oddziaływania (pośredni, bezpośredni) zagrożeń wewnętrznych i zewnętrznych na określony podmiot (rys. 1). Część taka powinna także być powiązana z wybranymi działami administracji rządowej oraz z charakterem sprawowanej ochrony, głównie przez wyspecjalizowane formacje państwowe. $Z$ wyłonionego zakresu pola badawczego wynikałaby domena nauki o bezpieczeństwie. Mówiąc o określonym podmiocie, konkretnej przestrzeni oraz konkretnym środowisku, autor ma na uwadze (generalnie) dwa podmioty - naród i jego państwo, które zajmują konkretną przestrzeń wśród innych narodów i państw stanowiących dla nich środowisko bliższe i dalsze. 
Rysunek 1. Zagrożenia - rodzaje, charakter i wzajemne oddziaływanie oraz zakresy i domeny nauk o bezpieczeństwie

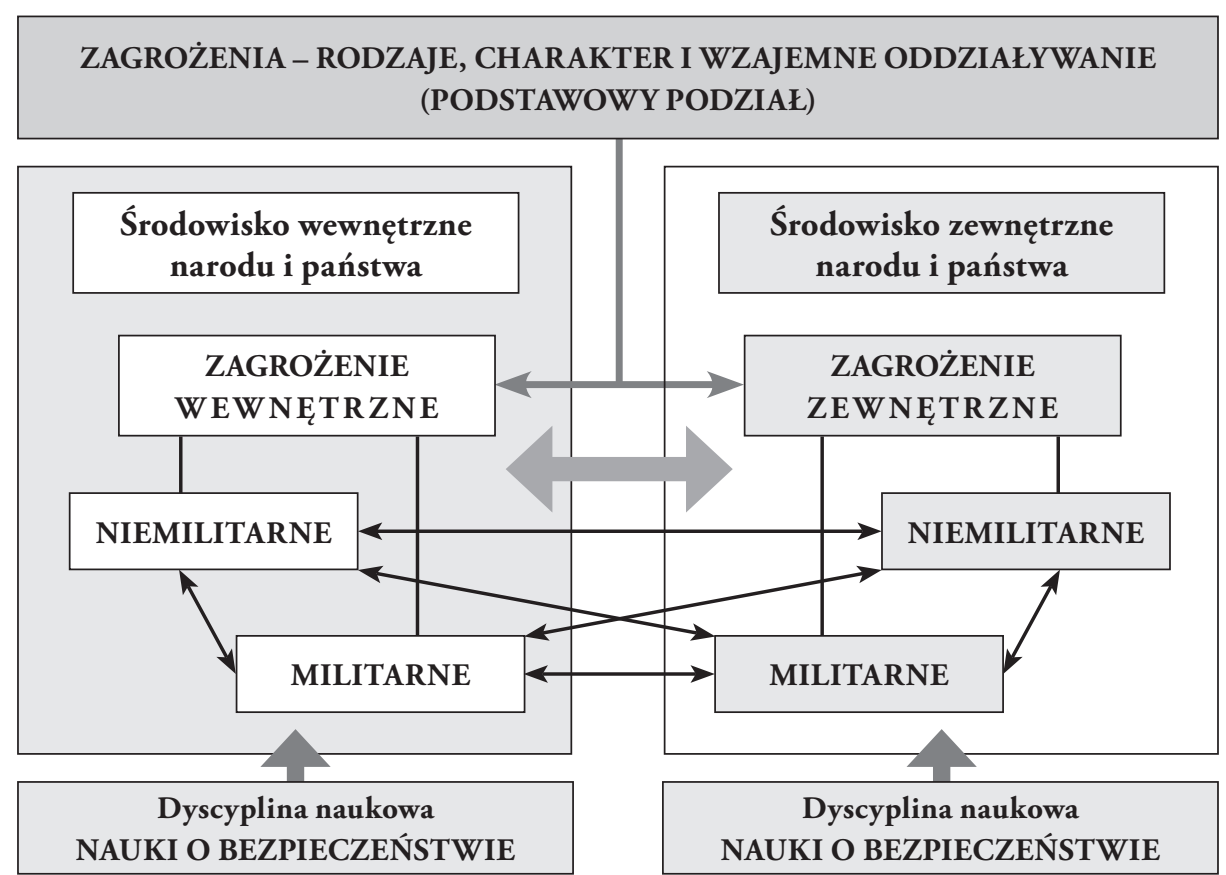

Źródło: opracowanie własne, na podstawie: Lutostański, 2015.

Natomiast wskazując na obszary (części) bezpieczeństwa szczególnie ważne dla życia i funkcjonowania oraz dla rozwoju tych podmiotów, odnosi je odpowiednio do ważnych obszarów aktywności organów władzy w państwie. W powiązaniu tych węzłowych elementów upatruje ponadto możliwość sprzężenia nauki z dydaktyką i praktyką, co pozwoli na to, że wiedza naukowa, płynąca z badań prowadzonych w wydzielonych częściach (obszarach) bezpieczeństwa, będzie mogła służyć narodowi i władzy do tworzenia organizacji zażegnywania zagrożeń. Do wydzielenia takich obszarów można zastosować „metodę jedności kryterium podstawowego podziału”: bezpieczeństwa, uwarunkowań i polityki bezpieczeństwa. Metoda taka pozwoli wskazać: bezpieczeństwo zewnętrzne oraz bezpieczeństwo wewnętrzne, uwarunkowania zewnętrzne oraz warunki wewnętrzne, politykę zagraniczną oraz politykę wewnętrzną (Lutostański, 2015). Autor uważa również, że takie kontekstowe podejście, a także użyta metoda (jedności) podziału obszarów aktywności władzy w państwie oraz ludzi nauki przyczyni się do osiągnięcia pożądanej spójności nauki, dydaktyki i praktyki. Kontekstowy charakter podstawowego podziału aktywności państwa w zakresie bezpieczeństwa, po- 
przez skatalogowanie problemów bezpieczeństwa w zgodności i we wspólnocie perspektyw nauki i administracji rządowej funkcjonujących w określonej rzeczywistości, przestrzeni oraz w konkretnym środowisku, pozwala zarówno na wskazanie konstytutywnych cech nauk o bezpieczeństwie (cechy wewnętrzne oraz cechy zewnętrzne), jak i na uporządkowanie zakresów pól badawczych, przedmiotów i celów badań oraz przypisanie ich dyscyplinom naukowym w jedności z wewnętrznym oraz zewnętrznym działami aktywności organów administracji rządowej. Można zatem uznać za zasadne zarekomendowanie wyłonienia w ramach obszaru nauk społecznych osobnej dziedziny nauki - „nauki o bezpieczeństwie” z dwoma dyscyplinami naukowymi: „nauki o bezpieczeństwie wewnętrznym” oraz „nauki o bezpieczeństwie zewnętrznym”, których celem byłoby nie tylko opisywanie przedmiotu poznania, lecz także rozwiązywanie rzeczywistych, praktycznych problemów w tych obszarach bezpieczeństwa.

Rozważając klasyfikację nauk o bezpieczeństwie, wypada również podnieść, że w aktualnym modelu klasyfikacji nauki daje się zauważyć brak technicznego aspektu bezpieczeństwa. W takiej sytuacji warto wskazać, mimo iż jest to wiedza powszechna, że współczesna rzeczywistość charakteryzuje się niespotykanym dotąd nasyceniem techniką, która wytwarzana jest z uwzględnieniem szerokich potrzeb bezpieczeństwa wewnętrznego oraz zewnętrznego. A skoro tak, to rośnie zapotrzebowanie na techniczną wiedzę innowacyjną, której potrzebują zarówno edukacja, jak i praktyka bezpieczeństwa. Za ważne źródło wytwarzania takiej wiedzy i innych pożytków o specjalistycznym, a nawet ultraspecjalistycznym charakterze uznać należy badania naukowe, które zasługują na prowadzenie w ramach autonomicznej dyscypliny naukowej (rys. 2). Uwzględniając powyższe, w tym fakt, że uczelnie kształcą studentów na kierunku inżynieria bezpieczeństwa, uprawniony wydaje się postulat wyodrębnienia w polskiej klasyfikacji nauk osobnej jednostki klasyfikacyjnej „inżynierii bezpieczeństwa” (Lutostański, 2016). Mając na uwadze charakter rozważań podjętych w tym opracowaniu, należy postawić pytanie o miejsce dyscypliny naukowej „inżynieria bezpieczeństwa” w klasyfikacji nauki. Za niewątpliwie innym ulokowaniem jej niż projektowana powyżej dziedzina "nauki o bezpieczeństwie” z dyscyplinami naukowymi „nauki o bezpieczeństwie wewnętrznym” oraz "nauki o bezpieczeństwie zewnętrznym” przemawiają podstawowe cechy określające dyscyplinę naukową. Uwzględniając przedmiot badań, metody badań oraz język badań, nietrudno zauważyć, że inżynieria bezpieczeństwa jest bliska naukom technicznym. A skoro tak, to za zasadne należy uznać rekomendowanie umiejscowienia takiej dyscypliny naukowej w dziedzinie nauk technicznych, obok dyscyplin naukowych - ,inżynieria rolnicza”, ,inżynieria środowiska”" (Lutostański, 2016). 
Rysunek 2. Ważniejsze pożytki płynące z wyodrębnienia autonomicznej dyscypliny naukowej

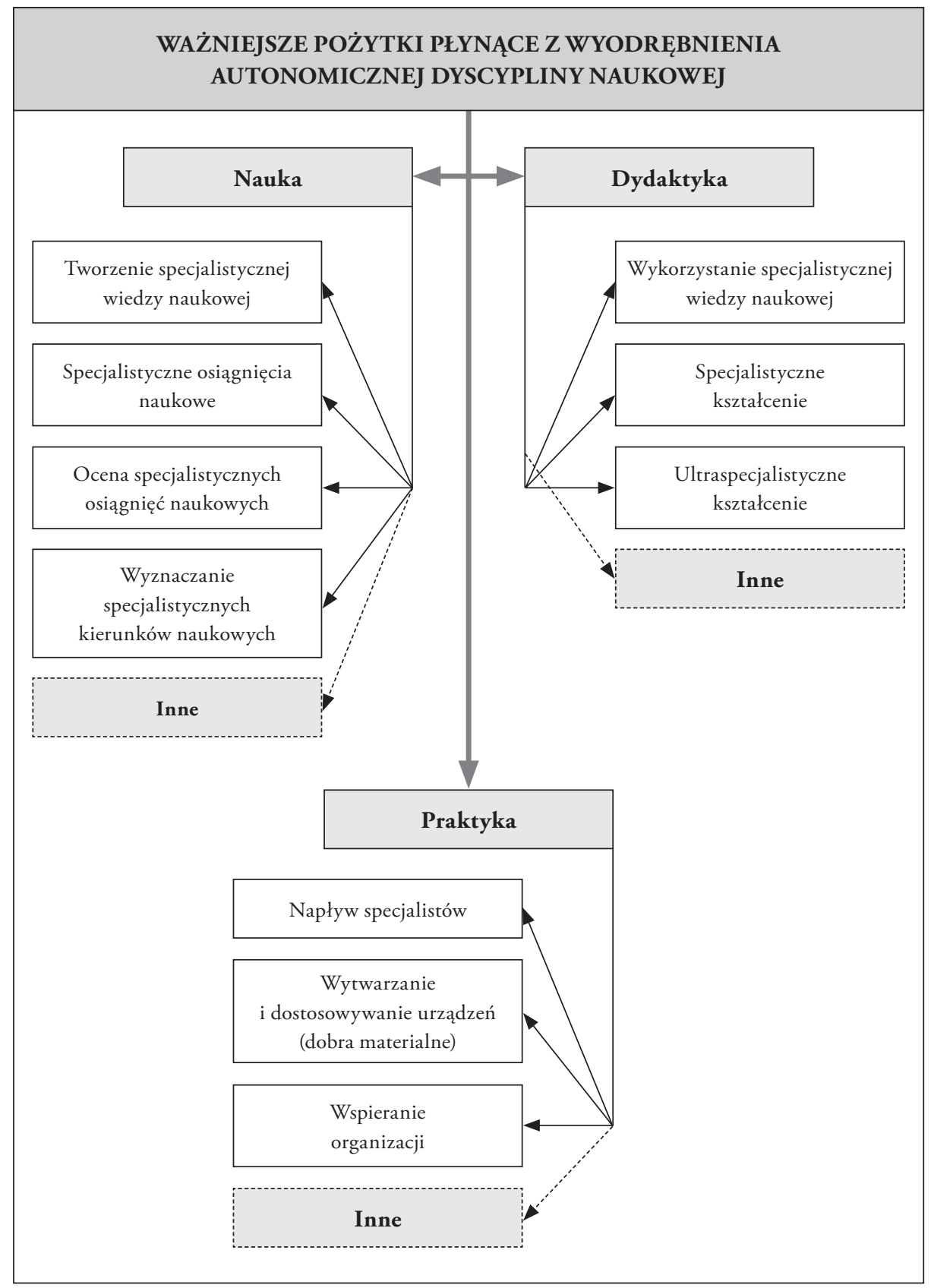

Źródło: opracowanie własne, na podstawie: Lutostański, 2016. 


\section{Podsumowanie}

Pogłębiona refleksja nad klasyfikacją nauki polskiej w części dotyczącej problemów bezpieczeństwa oraz nad literaturą przedmiotu pozwala przyjąć, że aktualna klasyfikacja nauk w rozważanym zakresie może być uznana za istotnie problematyczną. Świadczy o tym m.in. zazębiający się problem semantyczno-rzeczowy z niską konkretnością dyscypliny naukowej „nauki o bezpieczeństwie”. Problem semantyczno-rzeczowy powstaje na tle głównie ogólnego charakteru „nauk o bezpieczeństwie" i ich szerokiego zakresu badań, który obejmuje zakres badań innej dyscypliny naukowej - „nauk o obronności”. Nauki o obronności są de facto elementem nauk o bezpieczeństwie. Niska konkretność natomiast polega na nadmiernym uspołecznieniu tej dyscypliny - „nauki o bezpieczeństwie wszystkiego”. A skoro tak, to obecna systematyka nauk, w części dotyczącej problemów bezpieczeństwa, może wprowadzać dysonans poznawczy.

Uwzględniając zarówno teorię dyscypliny naukowej, jak i potrzebę zachowania jedności nauki z dydaktyką oraz praktyką bezpieczeństwa, rekomenduje się wyłonienie w obszarze nauk społecznych osobnych jednostek klasyfikacyjnych - dziedziny nauk o bezpieczeństwie z dwiema dyscyplinami naukowymi: „nauki o bezpieczeństwie wewnętrznym” oraz „nauki o bezpieczeństwie zewnętrznym”. Za domenę tych nauk przyjmuje się bezpieczeństwo narodu i państwa, związane sensu stricto $\mathrm{z}$ bezpieczeństwem wewnętrznym oraz z bezpieczeństwem zewnętrznym.

Mając na uwadze techniczny aspekt bezpieczeństwa, postuluje się również wyszczególnienie dyscypliny naukowej „inżynieria bezpieczeństwa” i umiejscowienie jej w dziedzinie nauk technicznych. Wyodrębnienie takiej dyscypliny jest szczególnie ważne dla procesów naukowych i edukacyjnych oraz dla praktyki bezpieczeństwa narodu i państwa.

\section{Bibliografia:}

Jarmoszko, S., Kalita, C., Maciejewski, J. (2016). Nauki społeczne wobec problemu bezpieczeñstwa (wybrane zagadnienia). Siedlce: Wyd. UP-H w Siedlcach.

Kitler, W. (2015). Transdyscyplinarność badań w naukach o bezpieczeństwie i w naukach o obronności. W: W. Kitler, T. Kośmider (red.), Metodologiczne i dydaktyczne aspekty bezpieczeństwa narodowego. Warszawa: Wydawnictwo Difin.

Krzyżanowski, L. (1999). O podstawach kierowania organizacjami inaczej: paradygmaty, filozofia, dylematy. Warszawa: Wydawnictwo PWN.

Lutostański, M. (2014). Gtówne komponenty architektury ochrony bezpieczeństwa państwa. Łódź-Warszawa: Wydawnictwo Społeczna Akademia Nauk w Łodzi. 
Lutostański, M. (2015). Podstawy bezpieczeństwa narodowego. Studium problemów teoretycznych. Toruń: Wydawnictwo Adam Marszałek.

Lutostański, M. (2015). O dylematach polskiej klasyfikacji nauk w zakresie bezpieczeństwa - wybrane problemy. W: K. Skibniewska, M. Lutostański (red.), Postęp w inżynierii bezpieczeństwa. Olsztyn: Wydawnictwo Uniwersytetu Warmińsko-Mazurskiego w Olsztynie.

Lutostański, M. (2016). Bezpieczeństwo. Uzupetniający komponent architektury ochrony bezpieczeństwa narodu i państwa. Warszawa: Wydawnictwo Difin.

Lutostański, M. (2016). Dylematy polskiej klasyfikacji nauk w zakresie bezpieczeństwa. Inżynieria bezpieczeństwa. Zeszyty Naukowe AON, 3(104). Warszawa: Akademia Sztuki Wojennej.

Pokruszyński, W. (2011). Filozoficzne aspekty bezpieczeństwa. Józefów: Wydawnictwo WSGE im. Alcide De Gasperi w Józefowie.

Rozporządzenie Ministra Nauki i Szkolnictwa Wyższego z dnia 8 sierpnia 2011 r. w sprawie obszarów wiedzy, dziedzin nauki i sztuki oraz dyscyplin naukowych i artystycznych (Dz.U. Nr 179, poz. 1065).

Sienkiewicz, P. (2013). Natura bezpieczeństwa w perspektywie systemowej. W: K. Drabik (red.), Natura bezpieczeństwa w perspektywie personalnej i strukturalnej. Warszawa: Wydawnictwo AON.

Sienkiewicz, P. (2015). Bariery metodologiczne w badaniach nad bezpieczeństwem narodowym. W: W. Kitler, T. Kośmider (red.), Metodologiczne i dydaktyczne aspekty bezpieczeństwa narodowego. Warszawa: Wydawnictwo Difin.

Szczepański, J. (2013). Dyscyplina nauk o polityce. Status teoretyczny i prawny. Spoteczeństwo i Polityka, 2(35).

Szarucki, M. (2013). Analiza nurtów metodologicznych $w$ naukach o zarządzaniu. Pobrane z: www.janek.uek. krakow.pl/-kzzo/1.3.1.pdf.

Trejnis, Z. (2011). Nauki o bezpieczeństwie nową dyscypliną w dziedzinie nauk społecznych? W: Z. Trejnis, B. Jagusik (red.), Studia bezpieczeństwa narodowego. Warszawa: Wydawnictwo WAT.

Wikin, J. (2012). Komu potrzebne są nauki społeczne? Nauki społeczne w polskiej i europejskiej przestrzeni badawczej oraz w rozwiązywaniu problemów rozwoju. Nauka, 4. Pobrane z: www.pan.poznan.pl/nauki/ N_412_02_Wilkin.pdf.

Wróblewski, R. (2015). Od nauk wojskowych do nauk o bezpieczeństwie. W: W. Kitler, T. Kośmider (red.), Metodologiczne i dydaktyczne aspekty bezpieczeństwa narodowego. Warszawa: Wydawnictwo Difin. 